\title{
(ESS) \\ Polybenzimidazole (PBI) Functionalized Nanographene as Highly Stable Catalyst Support for Polymer Electrolyte Membrane Fuel Cells (PEMFCs)
}

\author{
Le Xin, ${ }^{\mathrm{a}, *}$ Fan Yang,,${ }^{\mathrm{a}, \mathrm{b}, *}$ Yang Qiu, ${ }^{\mathrm{c}}$ Aytekin Uzunoglu, ${ }^{\mathrm{d}}$ Tommy Rockward, \\ Rodney L. Borup, ${ }^{\mathrm{e}, * *}$ Lia A. Stanciu, ${ }^{\mathrm{d}, \mathrm{f}}$ Wenzhen Li, ${ }^{\mathrm{e}, * *}$ and Jian Xie ${ }^{\mathrm{a}, * *, \mathrm{z}}$ \\ ${ }^{a}$ Department of Mechanical Engineering, Purdue School of Engineering and Technology, Indiana University-Purdue \\ University Indianapolis, Indianapolis, Indiana 46202, USA \\ ${ }^{b}$ School of Mechanical Engineering, Purdue University, West Lafayette, Indiana 47907, USA \\ ${ }^{c}$ Department of Chemical and Biological Engineering, Biorenewables Research Laboratory, Iowa State University, \\ Ames, Iowa 50011, USA \\ ${ }^{d}$ School of Materials Engineering, Purdue University, West Lafayette, Indiana 47907, USA \\ ${ }^{e}$ Materials Synthesis and Integrated Devices (MPA-11), Los Alamos National Laboratory, Los Alamos, \\ New Mexico 87545, USA \\ ${ }^{f}$ Weldon School of Biomedical Engineering, Purdue University, West Lafayette, Indiana 47907, USA
}

\begin{abstract}
Nanoscale graphenes were used as cathode catalyst supports in proton exchange membrane fuel cells (PEMFCs). Surface-initiated polymerization that covalently bonds polybenzimidazole (PBI) polymer on the surface of graphene supports enables the uniform distribution of the Pt nanoparticles, as well as allows the sealing of the unterminated carbon bonds usually present on the edge of graphene from the chemical reduction of graphene oxide. The nanographene effectively shortens the length of channels and pores for $\mathrm{O}_{2}$ diffusion/water dissipation and significantly increases the primary pore volume. Further addition of $p$-phenyl sulfonic functional graphitic carbon particles as spacers, increases the specific volume of the secondary pores and greatly improves $\mathrm{O}_{2}$ mass transport within the catalyst layers. The developed composite cathode catalyst of $\mathrm{Pt} / \mathrm{PBI}$-nanographene $(50 \mathrm{wt} \%)+\mathrm{SO}_{3} \mathrm{H}$-graphitic carbon black demonstrates a higher beginning of life (BOL) PEMFC performance as compared to both Pt/PBI-nanographene (50 wt $\%$ ) and $\mathrm{Pt} / \mathrm{PBI}$-graphene $(50 \mathrm{wt} \%)+\mathrm{SO}_{3} \mathrm{H}$-graphitic carbon black (GCB). Accelerated stress tests show excellent support durability compared to that of traditional Pt/Vulcan XC72 catalysts, when subjected to 10,000 cycles from $1.0 \mathrm{~V}$ to $1.5 \mathrm{~V}$. This study suggests the promise of using PBI-nanographene $+\mathrm{SO}_{3} \mathrm{H}-\mathrm{GCB}$ hybrid supports in fuel cells to achieve the $2020 \mathrm{DOE}$ targets for transportation applications.

(C) The Author(s) 2016. Published by ECS. This is an open access article distributed under the terms of the Creative Commons Attribution 4.0 License (CC BY, http://creativecommons.org/licenses/by/4.0/), which permits unrestricted reuse of the work in any medium, provided the original work is properly cited. [DOI: 10.1149/2.0921610jes] All rights reserved.
\end{abstract}

Manuscript submitted June 15, 2016; revised manuscript received August 15, 2016. Published August 25, 2016.

High stability is required for polymer electrolyte membrane fuel cells (PEMFCs) catalyst supports because they play a critical role in determining the overall durability of PEMFC systems. ${ }^{1}$ Carbon-based supports have been widely used to support Pt or Pt alloy catalysts in PEMFCs. ${ }^{2}$ High-surface-area carbon (HSAC) supports minimize the aggregation of the catalyst nanoparticles as HSAC provides more sites for catalyst to nucleate than low-surface-area-carbon (LSAC), thereby avoiding forming big aggregates. Thus, it increases the Pt utilization that leads to more active electro-catalysts with low platinum loadings $\left(<0.1 \mathrm{mg}-\mathrm{Pt} / \mathrm{cm}^{2}\right),{ }^{2}$ yet $\mathrm{HSAC}$ is vulnerable for corrosion due to the increased surface area. Good electrical conductivity of the carbon materials provides good electron transport. ${ }^{3}$ In addition, the random aggregates of the primary carbon particles help the distribution of ionomer to access the active sites during the fabrication of membrane electrode assemblies (MEA), and also allow the construction of a highly porous catalyst layer that enables $\mathrm{O}_{2}$ diffusion and the water dissipation in PEMFCs. The most commonly used carbon blacks in low temperature PEMFCs include Vulcan XC72 (Cabot Corp., USA), Black Pearls 2000 (Cabot Corp., USA) Ketjen Black EC300j (AkzoNobel Corp., the Netherlands), Ketjen Black EC600 (AkzoNobel Corp., the Netherlands), etc. These carbon blacks consist of inhomogeneous graphitic structures and amorphous carbons. ${ }^{4}$ The small size of the graphitic domains cause a high density of edge sites, (particularly in the case of high BET (Brunauer-Emmett-Teller) surface area carbon supports), in conjunction with amorphous carbon, both of which are vulnerable to the dynamic working conditions of PEMFCs. ${ }^{5,6}$ These carbon supports quickly corrode when exposed to local anode $\mathrm{H}_{2}$ starvation and $\mathrm{H}_{2}$ /air fronts during start-up/stop that can raise the the cathode interfacial potential to ca. $1.5 \mathrm{~V} .^{7-11}$ Although carbon is quite stable at potentials less than $0.55 \mathrm{~V}$ (vs.

\footnotetext{
*Electrochemical Society Student Member

**Electrochemical Society Member.

${ }^{\mathrm{z} E-m a i l: ~ j i a n x i e @ i u p u i . e d u ~}$
}

SHE), it has been reported that high temperatures (i.e. $80^{\circ} \mathrm{C}$ ), high relative humidity $(\mathrm{RH})$, and the presence of platinum particles accelerate the degradation of the carbon support. ${ }^{11-17}$ Consequently, the corrosion of the carbon supports causes three main issues: (1) the increased mobility of the catalyst nanoparticles, which, in turn, causes the migration/aggregation of the metal nanoparticles, their detachment from the carbon supports, and their isolation from the Nafion ionomer and results in a decrease of the electrochemical active surface area (ECSA) of the catalysts, ${ }^{18,19}$ (2) the reduced pore volume of the catalyst layer that is required for the mass transport of $\mathrm{O}_{2}$ and water; ${ }^{18}$ (3) the increased hydrophilicity of the carbon supports that decreases the $\mathrm{O}_{2}$ permeability because of the "flooding" of the pores. ${ }^{17,20-22}$ Extensive studies on the support durability in PEMFCs have motivated the development of corrosion-resistant carbon supports. ${ }^{4,5,10}$ Carbon supports with a high degree of graphitization (e.g. steam etched carbon blacks, ${ }^{23,24}$ graphitic carbon blacks, ${ }^{13,25,26}$ graphitized multiwall carbon nanotubes (MWCNTs), ${ }^{27,28}$ graphitic carbon nanocages (CNCs), ${ }^{29,30}$ nanographite, ${ }^{31}$ and graphitized mesoporous carbon $(\mathrm{MC})^{32}$ ) show improved stability in relation to non-graphitized carbon supports when subjected to accelerated stress tests (ASTs). Besides these studies that employed high-temperature $\left(>2500^{\circ} \mathrm{C}\right)$ treated carbon supports to enhance support durability, Tintula et al. reported a poly(3,4-ethylenedioxythiophene) (PEDOT) functionalized MC as a catalyst support for Pt nanoparticles that demonstrated higher resistance to carbon corrosion in relation to $\mathrm{Pt} / \mathrm{XC}-72$ carbon. The authors concluded that the interactions between PEDOT functional groups and $\mathrm{Pt}$ are responsible for stability improvement. ${ }^{33}$ More recently, Popov et al. developed highly durable hybrid cathode catalysts (HCCs) for PEMFCs that show excellent support durability and are close to the technical targets of the Fuel Cell Technology Office (FCTO) of the U.S. Department of Energy, FY 2020. These results are attributed to the increase of the carbon support graphitic structure as a result of high-temperature treatments and the stronger support-catalyst interaction due to the doping of nitrogen on the carbon support surface. ${ }^{34-36}$ 
Graphene synthesized from the exfoliation of graphite has a great potential in polymer electrolyte membrane fuel cell (PEMFC) applications. ${ }^{37,38}$ The highly graphitic structure composed of conjugated carbons endows the graphene with extremely high electric conductivity and chemical/electrochemical stability. ${ }^{39}$ While graphene is an attractive material, there are four major barriers when using graphene-supported Pt-based catalysts in PEMFCs: (1) the lack of bonding sites for catalyst landing on the basal plane of the graphene causes the migration/aggregations of $\mathrm{Pt}$ nanoparticles when subject to accelerated stress tests (ASTs); ${ }^{40}$ (2) 2D graphene sheets tends to restack back to the graphite structure through $\pi-\pi$ interactions, which can severely block the $\mathrm{O}_{2}$ diffusion and water dissipation and, consequently, retard the catalytic reactions, in particular when PEMFCs are operated at high current densities $\left(>1.5 \mathrm{~A} / \mathrm{cm}^{2}\right) ;{ }^{41-43}$ (3) the highly hydrophobic surface of graphene is difficult to wet when mixed with the Nafion ionomer particles in a catalyst ink, leading to a poor catalyst/ionomer interface; ${ }^{44}$ and (4) the exfoliation of natural graphite using the wet chemistry method usually yields graphene that contains some dangling carbon bonds and oxygenated functional groups in the plane and the edge of a graphene sheet, which can de-stabilizes its conjugated electronic structure and, consequently, negatively affect electronic conductivity and stability. ${ }^{45}$ Furthermore, when subjected to harsh potential cycling (e.g. 1.0-1.5 V; potentials which can be observed during start-up/stop or local fuel starvation), these defect sites are susceptible to be corroded quickly in PEMFCs. To overcome these barriers, we used a novel approach to transform the 2D graphene sheets into 3D composite materials with appropriate channels and pores to facilitate facile mass transport by developing highly stable, hierarchical polybenzimidazole (PBI)-grafted graphene hybrid-supported Pt catalysts for PEMFCs. ${ }^{46}$ In our previous study, PBI- functionalization was found to homogenize the chemical environment of the graphene surface, resulting in a uniform dispersion of Pt nanoparticles that exposes more active sites for electro-catalytic reactions. Meanwhile, Pt particles were strongly anchored on PBI-graphene so that their migration/agglomeration was effectively reduced. Additionally, graphitized carbon particles were introduced to enlarge the gap between graphene sheets, which results in fast oxygen diffusion/water dissipation and overall higher MEA performance. Although the $\mathrm{Pt} / \mathrm{PBI}$-graphene + spacer hybrid cathode demonstrated excellent support durability in PEMFCs, the MEA performance, particularly at high current densities $\left(>1.5 \mathrm{~A} / \mathrm{cm}^{2}\right)$ requires further improvement to realize broad application of the stable graphene support in PEMFCs.

In this study, nanographene was synthesized employing platelet graphite nanofibers followed by the surface functionalization of PBI polymers. The PBI polymers were covalently grafted onto graphene sheets via diazonium reaction, ${ }^{46,47}$ that presumably prefers bonding to the defect sites due to their high activity. Hence, potentially, the PBI could seal the defects in the plane and edge of graphene sheets, to improve the graphene stability. The resulting nanographene sheets in corporation of the oppositely charged graphitic carbon black spacers $\left(\mathrm{SO}_{3} \mathrm{H}-\mathrm{GCB}\right)$ could help to lead to 3D graphene composites with much shorter lengths of channels and pores than those of normal graphene composites which is believed to cause the low performance at high current density. Such shorter channels and pores with the nanographene composites will further improve high current density performance of PBI-graphene-supported catalysts from our previous work. Both the primary and secondary specific pore volume of the catalyst layer made from Pt/PBI-graphene $(\mathrm{G})$ and $\mathrm{Pt} / \mathrm{PBI}$-nanographene (NG) with and without $\mathrm{SO}_{3} \mathrm{H}-\mathrm{GCB}$ was determined and compared using the mercury porosimetry technique. The specific pore volume distributions are then correlated with the PEMFC performance of the focus centers on the in-depth analysis of the polarization curves at both low current density $\left(<0.1 \mathrm{~A} / \mathrm{cm}^{2}\right)$ and high current density $\left(>1.5 \mathrm{~A} / \mathrm{cm}^{2}\right)$. Furthermore, the support durability of Pt/PBI-NG is evaluated under potential cycling between 1.0 and $1.5 \mathrm{~V}$ for 10,000 cycles and compared with commercial $\mathrm{Pt} / \mathrm{C}$.

\section{Experimental}

Surface functionalization of graphene and nanographene.Graphene oxide (GO) was synthesized using the Hummers method from graphite flakes (Asbury Carbons, $50-800 \mu \mathrm{m}$ in diameter) or platelet graphite nanofibers (H700, Catalytic Materials LLC, average width of $80 \mathrm{~nm}){ }^{48}$ To partially recover the $\mathrm{sp}^{2}$ carbon, GO was pre-reduced by adding $\mathrm{NaBH}_{4}$ to a $100 \mathrm{ml} \mathrm{GO}$ aqueous dispersion $(1 \mathrm{mg} / \mathrm{ml})$ that was then heated to $80^{\circ} \mathrm{C}$ and held for 1 hour. The mildly reduced graphene oxide (mrGO) was collected by centrifuge and washed with DI $\mathrm{H}_{2} \mathrm{O}$. Subsequently, the mrGO was re-dispersed in DI $\mathrm{H}_{2} \mathrm{O}$ and subjected to the diazonium functionalization reported in our previous studies: ${ }^{46,47}$ equal molar of 4-aminobenzoic acid, concentrated hydrochloric acid, and sodium nitrite were added in the mrGO aqueous dispersion that was then kept at $60^{\circ} \mathrm{C}$ for 4 hours. The $\mathrm{COOH}-\mathrm{mrGO}$ that was separated by centrifuge and rinsed using DI $\mathrm{H}_{2} \mathrm{O}$ /ethanol for multiple times again dispersed in DI $\mathrm{H}_{2} \mathrm{O}$. Hydrazine was then introduced to the above dispersion, and the reaction mixture was refluxed at $100^{\circ} \mathrm{C}$ overnight with constant stirring, yielding $\mathrm{COOH}$-graphene. Next, the $\mathrm{COOH}$-graphene, isophthalic acid, and $3,3^{\prime}$-diaminobenzidine were added into polyphosphoric acid $(115 \%$ $\mathrm{H}_{3} \mathrm{PO}_{4}$ basis). The mixture was stirred at $150^{\circ} \mathrm{C}$ for $1 \mathrm{~h}$, and then heated to $190-210^{\circ} \mathrm{C}$ and held overnight $(16 \mathrm{~h}$ ) under a nitrogen blanket. At the end of the reaction, the temperature was further raised to $220^{\circ} \mathrm{C}$, then the viscous solution was poured into ice water. Finally, the precipitated product (Polybenzimidazole (PBI)-graphene or -nanographene) was neutralized with the ammonium solution, washed with copious $\mathrm{DI} \mathrm{H} \mathrm{H}_{2} \mathrm{O}$ /methanol, and dried in a vacuum oven at $80^{\circ} \mathrm{C}$.

Preparation of Pt nanoparticles supported on Polybenzimidazole (PBI) functionalized nanographene and graphene.-The deposition of Pt nanoparticles with a loading of ca. $50 \mathrm{wt} \%$ on PBI-nanographene or PBI-graphene was carried out using a modified ethylene glycol (EG) method. ${ }^{46,47,49}$ Briefly, PBI-nanographene or PBI-graphene was added to an EG aqueous solution (EG/DI $\mathrm{H}_{2} \mathrm{O}: 3 / 2 \mathrm{v} / \mathrm{v}$ ) and ultra-sonicated for $30 \mathrm{~min}$. After the temperature of the oil bath was elevated to $140^{\circ} \mathrm{C}$, an aqueous EG solution of $\mathrm{H}_{2} \mathrm{PtCl}_{6} \cdot 6 \mathrm{H}_{2} \mathrm{O}$ was quickly injected in to the mixture that was then refluxed under constant stirring for 6 hours. Finally, the resulting suspensions were allowed to cool down to room temperature and $\mathrm{Pt} / \mathrm{PBI}$-nanographene or $\mathrm{Pt} / \mathrm{PBI}$-graphene were separated by filtration and washed with $\mathrm{DI} \mathrm{H}_{2} \mathrm{O}$ thoroughly. The obtained PBI-nanographene or PBI-graphene-supported Pt catalysts were dried in a vacuum oven at $60^{\circ} \mathrm{C}$ overnight.

Physical characterizations.-The particle size and distribution of Pt deposited on PBI-nanographene and PBI-graphene were characterized by a JEOL-2100F transmission electron microscope (TEM) operated at $200 \mathrm{kV}$. The average particle sizes were calculated by counting 400 randomly selected Pt primary particles in TEM images excluding the extremely large agglomerates. The morphology of the different functional graphene supported catalysts were characterized by JEOL-7800 field emission scanning electron microscope (FESEM). The pore size distribution and the specific pore volume in the catalyst layers were measured using Autopore IV 9520 mercury porosimeter (Micromeritics, Norcross, GA). The pore size was determined by assuming the pores are of cylindrical shape and using the Washburn equation that builds a positive relationship between the external pressure and the pore diameters. ${ }^{50,51}$ The XPS measurements were performed using a Kratos Amicus/ESCA 3400 instrument. The sample was irradiated with $240 \mathrm{~W}$ unmonochromatic $\mathrm{Mg} \mathrm{K} \alpha$ x-rays, and photoelectrons emitted at $0^{\circ}$ from the surface normal were energy analyzed using a DuPont type analyzer. The pass energy was set at $75 \mathrm{eV}$ for narrow scans of C 1s spectra. All spectra were energy calibrated with measured $\mathrm{C} 1 \mathrm{~s}$ peak position at $284.6 \mathrm{eV}$. CasaXPS was used to process raw data files.

Membrane electrode assembly (MEA) fabrication.-MEAs were fabricated via the catalyst-coated membrane (CCM) method by which 
the anode catalyst commercial Pt/XC72 CB (Pt/C, $20 \mathrm{wt} \%$, ETEK, $\mathrm{BASF}$ ) and the cathode catalyst Pt/PBI-NG or Pt/PBI-G (with or without the addition of the spacer) were spray coated on the respective sides of $\mathrm{H}^{+}$exchanged membrane (Nafion 212, thickness of 50 $\mu \mathrm{m})$. The Pt loadings on the MEA were determined by weighing the Nafion membrane before and after the catalyst spray-coating. The anode electrodes had a loading of $0.1 \pm 0.02 \mathrm{mg}-\mathrm{Pt} / \mathrm{cm}^{2}$, while the $\mathrm{Pt}$ loadings on the cathode were $0.11 \pm 0.02 \mathrm{mg}-\mathrm{Pt} / \mathrm{cm}^{2}$ for Pt/PBI$\mathrm{NG}, 0.09 \pm 0.02 \mathrm{mg}-\mathrm{Pt} / \mathrm{cm}^{2}$ for Pt/PBI-NG with spacer, and 0.11 $\pm 0.02 \mathrm{mg}-\mathrm{Pt} / \mathrm{cm}^{2}$ for $\mathrm{Pt} / \mathrm{PBI}-\mathrm{G}$ with the spacer. The catalyst ink was prepared by blending the catalyst powder with a Nafion ionomer suspension (5 wt \%, Ion Power, Inc.) in the DI $\mathrm{H}_{2} \mathrm{O} / 2$-propanol (4:1 $\mathrm{v} / \mathrm{v})$ solution via ultra-sonication for $60 \mathrm{~min}$. followed by high-speed stirring for another $30 \mathrm{~min}$. The $p$-phenyl sulfonic acid functionalized graphitized carbon blacks $\left(\mathrm{SO}_{3} \mathrm{H}-\mathrm{GCBs}\right)$ of equal weight were mixed in the catalyst ink containing Pt/PBI-NG and Pt/PBI-G suspensions. The electrostatic force induced by the electrostatic interaction between the positively charged PBI-NG/PBI-G and the negatively charged $\mathrm{SO}_{3} \mathrm{H}-\mathrm{GCB}$ allowed the self-assembly and the successful insertion of the carbon black particles into the graphene sheets. The ionomer-to-carbon weight ratio on both sides of all the MEAs was set to 0.54 . The MEA had an active cross-sectional area of $5 \mathrm{~cm}^{2}$ and was hot pressed between the two decals at $135^{\circ} \mathrm{C}$ at $600 \mathrm{psig}$ for $1.5 \mathrm{~min}$.

Beginning of life (BOL) performance tests.-The MEA performance was tested on a fuel cell test station (Fuel Cell Technologies, Inc., Albuquerque, NM, USA). The MEA was sandwiched between two gas diffusion layers (25BC, hydrophobic microporous layer coated, SGL Group) and assembled in fuel cell test hardware that consisted of a pair of POCO graphite blocks machined with a serpentine flow channel and a pair of gold-plated current collectors. Subsequently, high purity $\mathrm{H}_{2}(99.999 \%)$ and $\mathrm{O}_{2}(99.999 \%)$ were supplied into the anode and cathode chambers with a constant flow rate of 250 standard cubic centimeters per minute $(\mathrm{sccm})$ and $300 \mathrm{sccm}$, respectively, at the same absolute back-pressure of $280 \mathrm{kPa}$. The cell temperature was $80^{\circ} \mathrm{C}$, and the relative humidity ( $\left.\mathrm{RH}\right)$ for both anode and cathode was $100 \%$. The cell was conditioned (break-in) by square wave potential cycling in which the cell voltage was held at $0.2 \mathrm{~V}$ for 1 hour and then switched to hold at $0.5 \mathrm{~V}$ for 1 hour ( 2 hours/cycle for a total of 10 cycles, 20 hours).

After MEA break-in, the electrochemical active surface area (ECSA) of the cathode was measured employing a cyclic voltammogram $(\mathrm{CV})$ where potentials were cycled between $0.05 \mathrm{~V}$ and $0.6 \mathrm{~V}$ at a sweeping rate of $20 \mathrm{mV} / \mathrm{s}$. High purity $\mathrm{H}_{2}(99.999 \%)$ flowed over the anode, serving as the reference (RE) and counter electrode (CE), while high purity $\mathrm{N}_{2}(99.999 \%)$ flowed over the cathode (working electrode, WE). The measurements were carried out at cell temperature of $80^{\circ} \mathrm{C}, 100 \% \mathrm{RH}$ and at $100 \mathrm{kPa}$ (absolute) until the open circuit voltage $(\mathrm{OCV})$ was stable at ca. $0.1 \mathrm{~V}$. ECSAs were calculated by integrating the charge associated with the hydrogen adsorption in the voltage range of $0.05 \mathrm{~V}-0.4 \mathrm{~V}$ and dividing by $210 \mu \mathrm{C} / \mathrm{cm}^{2}$, cell active area $\left(5 \mathrm{~cm}^{2}\right)$, and Pt loading.

$\mathrm{H}_{2}$ cross-over current density was measured under $\mathrm{H}_{2}$ on the anode and $\mathrm{N}_{2}$ on the cathode at $80^{\circ} \mathrm{C}, 100 \% \mathrm{RH}$ and an outlet pressure of $280 \mathrm{kPa}$ (absolute). Linear scan voltammetry (LSV) was carried out by scanning the potential from $0.05 \mathrm{~V}$ to $0.4 \mathrm{~V}$ vs. RE/CE at a scan rate of $2 \mathrm{mV} / \mathrm{s}$.

After the cell characterization, high purity $\mathrm{H}_{2}$ and $\mathrm{O}_{2}(99.999 \%)$ were fed into the anode and cathode with a constant flow rate of 250 and $300 \mathrm{sccm}$, respectively, at the same absolute back-pressure of 280 $\mathrm{kPa}$. The cell temperature was $80^{\circ} \mathrm{C}$, and the relative humidity for both anode and cathode was $100 \%$. Voltage-current (VI) polarization curves were recorded at the scanning current mode from open circuit voltage $(\mathrm{OCV})$ to limiting current density with each step point held for $1 \mathrm{~min}$.

Accelerated stress test (AST) protocols for support durability studies.-ASTs were performed by cycling the potentials from 1.0 $\mathrm{V}$ to $1.5 \mathrm{~V}$ vs. RE/CE (triangle wave) under $\mathrm{H}_{2} / \mathrm{N}_{2}$ (constant flow of
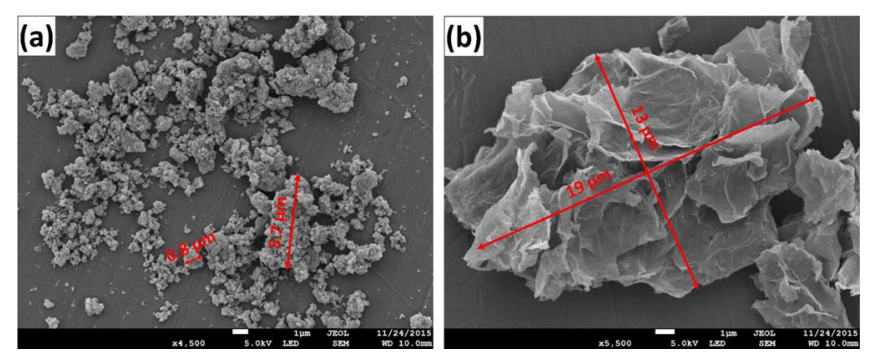

Figure 1. FESEM images of (a) PBI-NG, (b) PBI-G

$250 / 300 \mathrm{sccm}$ ) at $80^{\circ} \mathrm{C}$ and $100 \% \mathrm{RH}$ for 10,000 cycles. Polarization curves were recorded following the BOL testing protocols described above after $0,500,1000$, and 10,000 cycles under $\mathrm{H}_{2} / \mathrm{O}_{2}$ at $80^{\circ} \mathrm{C}$ and $100 \%$ RH, $280 \mathrm{Kpa}$ (absolute) back pressure.

\section{Results and Discussion}

The FESEM images shown in Fig. 1a present the PBI-NG sheets synthesized by the chemical exfoliation of platelet graphite nanofibers stacked together to form the aggregates with sizes of ca. $0.8-5.7 \mu \mathrm{m}$, whereas the dimensions of the closely packed PBI-G sheets prepared from graphite flakes were in the range of 13-19 $\mu \mathrm{m}$ (Fig. 1b). The graphene layers were further characterized by high resolution TEM, where the low magnification images clearly reveal the size differences between the PBI-NG films $(0.27 \mu \mathrm{m})$ and the PBI-G stacks $(1.9 \mu \mathrm{m})$ (Fig. 2a vs. Fig. 2d). Fig. 2b and Fig. 2e also show the highly dispersed Pt nanoparticles on both supports. Few aggregations of Pt particles were observed while the loading ratio on the graphene supports was as high as $50 \mathrm{wt} \% \mathrm{Pt} / \mathrm{PBI}-\mathrm{G}$. This is largely attributed to the covalently grafted PBI polymers on the graphene surface, which assists the $\mathrm{Pt}$ deposition to result in a more homogenous distribution. The average primary nanoparticle size of Pt over PBI-NG was calculated to be ca. $2.3 \mathrm{~nm}$, ranging from $1.0 \mathrm{~nm}-3.5 \mathrm{~nm}$. A similar uniformity of Pt nanoparticles in a range from $1.0 \mathrm{~nm}-4.0 \mathrm{~nm}$ was deposited on PBI-G with an average size of $2.4 \mathrm{~nm}$.

The broad application of graphene supports in PEMFCs is impeded by the face-to-face stacking of the isolated graphene sheets when drying the graphene dispersions to fabricate the catalyst layers. The decrease of the interlayer spacing inhibits the supply of $\mathrm{O}_{2}$ gas, which is needed to sustain the oxygen reduction reactions (ORRs) in PEMFC operations. Additionally, the aggregations of hydrophobic graphene sheets during catalyst ink preparation close the access of the solvated ionomer particles to the Pt nanoparticles, causing incomplete ionomer coverage over the Pt catalysts. Therefore, we introduced a graphitized carbon black (GCB) whose surface was functionalized by a $p$-phenyl $\mathrm{SO}_{3} \mathrm{H}$ - group. When $\mathrm{SO}_{3} \mathrm{H}-\mathrm{GCB}$ was mixed with $\mathrm{PBI}$-graphene in an aqueous solution, the acid-base reactions drive the functional graphene GCB particles into the gaps of graphene films. Fig. 3 shows that $\mathrm{SO}_{3} \mathrm{H}-$ GCB adheres on both sides of the PBI-NG/PBI-G surface, preventing the van der Waals force between the neighboring graphene sheets.

The pore size distributions of the catalyst layers (CLs) were then calculated from the intrusion curves obtained by the mercury porosimetry measurement. The samples were prepared by spraycoating the catalyst inks blended with Nafion ionomer (30 wt\% with respect to the total solid content in the catalyst ink) on both sides of the Nafion membrane. This fabrication protocol is the same as that used to make MEAs, leading to a direct correlation between the microstructure of the CL in MEAs and the MEA performance. Therefore, useful information can be provided for modeling and simulation work to guide the diagnosis and designs of MEA and PEMFC systems. Results shown in Fig. 4 suggest that the contribution of Nafion membrane substrates to the total pore volumes of the CL samples is negligible since no intrusion can be observed between pore diameters of $3 \mathrm{~nm}-3000 \mathrm{~nm}$. The investigation of the pore size distribution curves of the different CLs show that two pore ranges exist: $3 \mathrm{~nm}-20 \mathrm{~nm}$ 

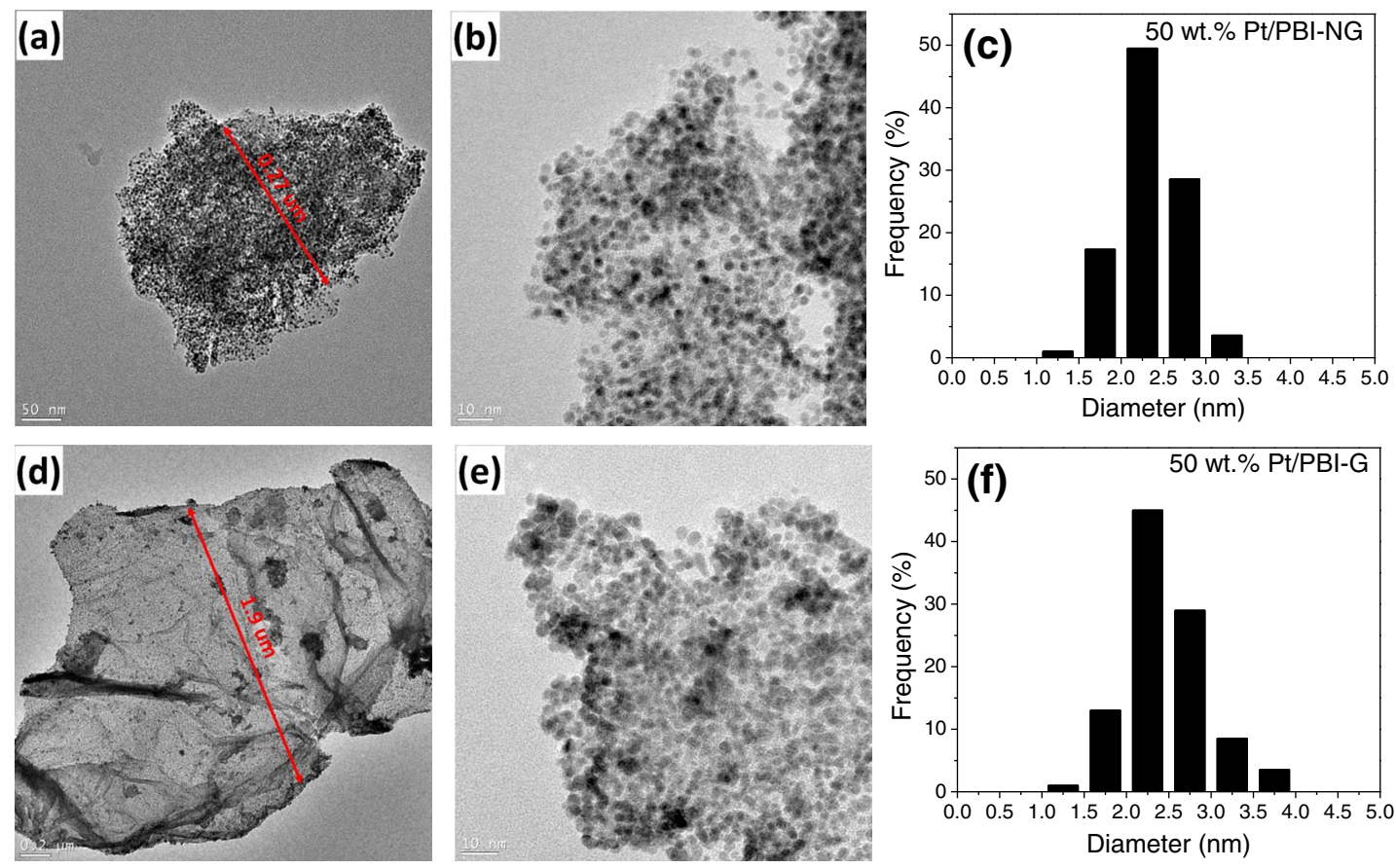

Figure 2. TEM images and particle size distributions of (a-c) Pt/PBI-NG (50 wt $\%$ ) and (d-f) Pt/PBI-G (50 wt $\%$ ).
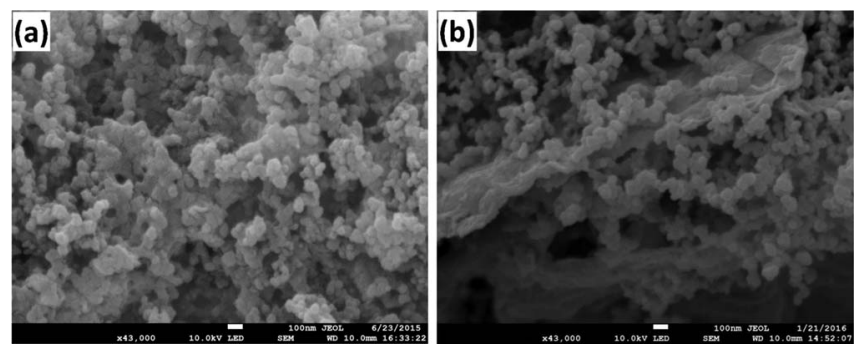

Figure 3. SEM images of (a) PBI-NG $+\mathrm{SO}_{3} \mathrm{H}-\mathrm{GCB}(1: 1 \mathrm{w} / \mathrm{w})$ and (b) $\mathrm{PBI}-\mathrm{G}$ $+\mathrm{SO}_{3} \mathrm{H}-\mathrm{GCB}(1: 1 \mathrm{w} / \mathrm{w})$

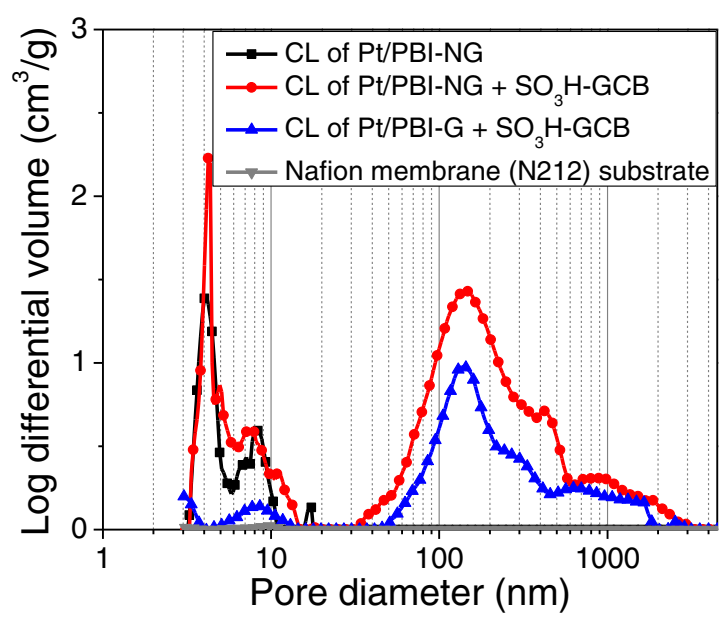

Figure 4. Specific pore volume distribution curves of Nafion membrane (N212) substrate and three different catalyst layer samples: Pt/PBI-NG, Pt/PBI$\mathrm{NG}+\mathrm{SO}_{3} \mathrm{H}-\mathrm{GCB}$, and $\mathrm{Pt} / \mathrm{PBI}-\mathrm{G}+\mathrm{SO}_{3} \mathrm{H}-\mathrm{GCB}$. Nafion ionomer content: 30 wt $\%$ with respect to the total mass. and $20 \mathrm{~nm}-3000 \mathrm{~nm}$. The pores sizes smaller than $20 \mathrm{~nm}$ are the primary pores that are attributed to the interlayer distance between the individual graphene sheets, while the larger pores of $>30 \mathrm{~nm}$ are considered to be the secondary pores and are associated with the spaces between the graphene aggregates. The pore size distribution boundary of $20 \mathrm{~nm}$ is in good agreement with that reported by Xie et al. $(17 \mathrm{~nm}),{ }^{50}$ but is much smaller than that identified by Uchida et al. $(40 \mathrm{~nm}){ }^{51}$ These discrepancies can be derived from the different methods employed to prepare the CLs.

In the CL of Pt/PBI-NG, only the primary pores of $0.31 \mathrm{~cm}^{3} / \mathrm{g}$ can be found (Fig. 4 and Table I). This confirms the restacking issue when handling $2 \mathrm{D}$ graphene materials. In the 2-propanol/ $\mathrm{H}_{2} \mathrm{O}$ solvent, the Nafion ionomer forms rod-like particles with dimensions of 15 to $25 \AA$ in radius and 125 to $350 \AA$ in length. ${ }^{52-54}$ The small gaps of $<20 \mathrm{~nm}$ make the ionomer particles difficult to orient and penetrate into the narrow channels of the graphene films. As a consequence, the majority of the ionomer particles might accumulate and fill the pores between the graphene agglomerates, resulting in the absence of the secondary pores. When the $\mathrm{SO}_{3} \mathrm{H}-\mathrm{GCBs}$ was introduced, the primary pore volume slightly increased to $0.35 \mathrm{~cm}^{3} / \mathrm{g}$, suggesting that it helps, to a small extent, the exfoliation and dispersion of the PBInanographene during the ink preparation to enlarge the distances of the graphene interlayers. The most important observation, as shown in Fig. 4, is the emergence of the secondary pores, which indicates that the inserted $\mathrm{SO}_{3} \mathrm{H}-\mathrm{GCB}$ particles mainly prevent the stacking of the nanographene aggregates. On the other hand, the volume of

Table I. Summary of the porosimetry of different catalyst layers.

\begin{tabular}{ccc} 
Samples & $\begin{array}{c}\text { Pore volume } \\
\left(\mathrm{cm}^{3} / \mathrm{g}\right)\end{array}$ & $\begin{array}{c}\text { Pore ranges } \\
(\text { Diam } \mathrm{nm})\end{array}$ \\
\hline Nafion membrane (N212) & 0.00 & $3-3000$ \\
Pt/PBI-NG & 0.31 & $3-20$ (primary) \\
& 0.00 & $20-3000$ (secondary) \\
Pt/PBI-NG $+\mathrm{SO}_{3} \mathrm{H}-\mathrm{GCB}$ & 0.35 & $3-20$ (primary) \\
& 1.07 & $20-3000$ (secondary) \\
Pt/PBI-G $+\mathrm{SO}_{3} \mathrm{H}-\mathrm{GCB}$ & 0.04 & $3-20$ (primary) \\
& 0.58 & $20-3000$ (secondary)
\end{tabular}




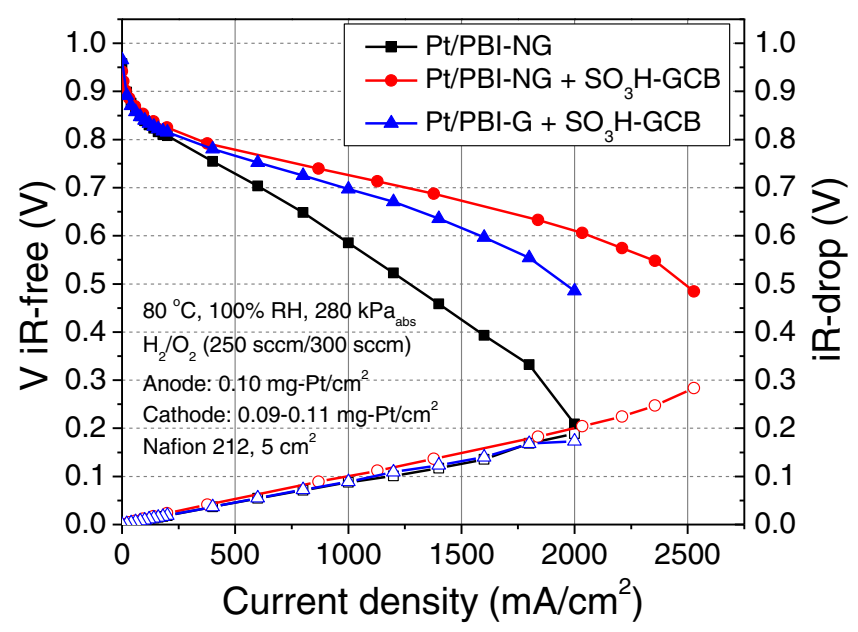

Figure 5. The beginning of life for $\mathrm{H}_{2} / \mathrm{O}_{2}$ PEMFC polarization curves with different cathode catalysts.

the secondary pores of the CL with $\mathrm{Pt} / \mathrm{PBI}-\mathrm{NG}+\mathrm{SO}_{3} \mathrm{H}-\mathrm{GCB}(1.07$ $\mathrm{cm}^{3} / \mathrm{g}$ ) is also much larger than that of the CL with Pt/PBI-G + $\mathrm{SO}_{3} \mathrm{H}-\mathrm{GCB}\left(0.58 \mathrm{~cm}^{3} / \mathrm{g}\right)$, as shown in Table I. This is because the reduction of the graphene size shortens the length of the channels, which eases the penetration of the $\mathrm{SO}_{3} \mathrm{H}-\mathrm{GCB}$ particles so they can expand the secondary pores. Another interesting observation from Fig. 4 and Table I is the smallest pore volume $\left(0.04 \mathrm{~cm}^{3} / \mathrm{g}\right)$ noticed in the $\mathrm{Pt} / \mathrm{PBI}-\mathrm{G}+\mathrm{SO}_{3} \mathrm{H}-\mathrm{GCB}$ composite CL. This small volume is likely
Table II. Comparison of mass activity, ECSA, and cell potentials
of Pt/PBI-NG, Pt/PBI-NG $+\mathrm{SO}_{3} \mathrm{H}-\mathrm{GCB}$, and $\mathrm{Pt} / \mathrm{PBI}-\mathrm{G}+\mathrm{SO}_{3} \mathrm{H}-$ GCB catalysts.

\begin{tabular}{cccc} 
Samples & $\begin{array}{c}\text { Mass activity } \\
\text { at } 0.9 \mathrm{~V}_{\text {iR-free }} \\
(\mathrm{mA} / \mathrm{mg}-\mathrm{Pt})\end{array}$ & $\begin{array}{c}\text { ECSA } \\
\left(\mathrm{m}^{2} / \mathrm{g}-\mathrm{Pt}\right)\end{array}$ & $\begin{array}{c}\text { Cell potential } \\
\text { at } 0.8 \mathrm{~A} / \mathrm{cm}^{2} \\
\left(\mathrm{mV}_{\mathrm{iR}-\text {-free }}\right)\end{array}$ \\
\hline Pt/PBI-NG & 219.7 & 25.3 & 648 \\
$\mathrm{Pt} / \mathrm{PBI}-\mathrm{NG}+\mathrm{SO}_{3} \mathrm{H}-\mathrm{GCB}$ & 240.9 & 27.7 & 747 \\
$\mathrm{Pt} / \mathrm{PBI}-\mathrm{G}+\mathrm{SO}_{3} \mathrm{H}-\mathrm{GCB}$ & 237.0 & 25.8 & 725
\end{tabular}

because the folded graphene edges seal the interlayer void spaces, making them inaccessible upon mercury intrusion.

The beginning of life (BOL) performance represented by voltagecurrent (V-I) curves is shown in Fig. 5 for $\mathrm{H}_{2} / \mathrm{O}_{2}$. The V-I curves were corrected for membrane resistance and contact resistance between the electronic components of the fuel cell test hardware in order to allow for the investigation of MEA activity. As summarized in Table II, the ECSA of Pt/PBI-NG $+\mathrm{SO}_{3} \mathrm{H}-\mathrm{GCB}\left(27.7 \mathrm{~m}^{2} / \mathrm{g}-\mathrm{Pt}\right)$ is slightly higher than that of both Pt/PBI-NG $\left(25.3 \mathrm{~m}^{2} / \mathrm{g}-\mathrm{Pt}\right)$ and Pt/PBI-G $+\mathrm{SO}_{3} \mathrm{H}-\mathrm{GCB}\left(25.8 \mathrm{~m}^{2} / \mathrm{g}-\mathrm{Pt}\right)$, resulting in a higher mass activity (240.9 mA/mg-Pt on Pt/PBI-NG $+\mathrm{SO}_{3} \mathrm{H}-\mathrm{GCB}$ as compared to 219.7 $\mathrm{mA} / \mathrm{mg}$-Pt on Pt/PBI-NG and $237.0 \mathrm{~mA} / \mathrm{mg}-\mathrm{Pt}$ on Pt/PBI-G $+\mathrm{SO}_{3} \mathrm{H}-$ $\mathrm{GCB}$ ). In addition, the increase in the secondary pore volume is, likely, a major factor that helps the ionomer particles access the reaction sites, which is observed as a lower slope in the middle-high current region of the $\mathrm{H}_{2} / \mathrm{O}_{2}$ polarization curves for the Pt/PBI-NG $+\mathrm{SO}_{3} \mathrm{H}$ GCB composite cathode, suggesting a lower ionic resistance. Table II shows the V-I curves at $0.8 \mathrm{~A} / \mathrm{cm}^{2}$ with a $99 \mathrm{mV}$ and a $22 \mathrm{mV}$ higher performance for Pt/PBI-NG $+\mathrm{SO}_{3} \mathrm{H}-\mathrm{GCB}(747 \mathrm{mV})$ than
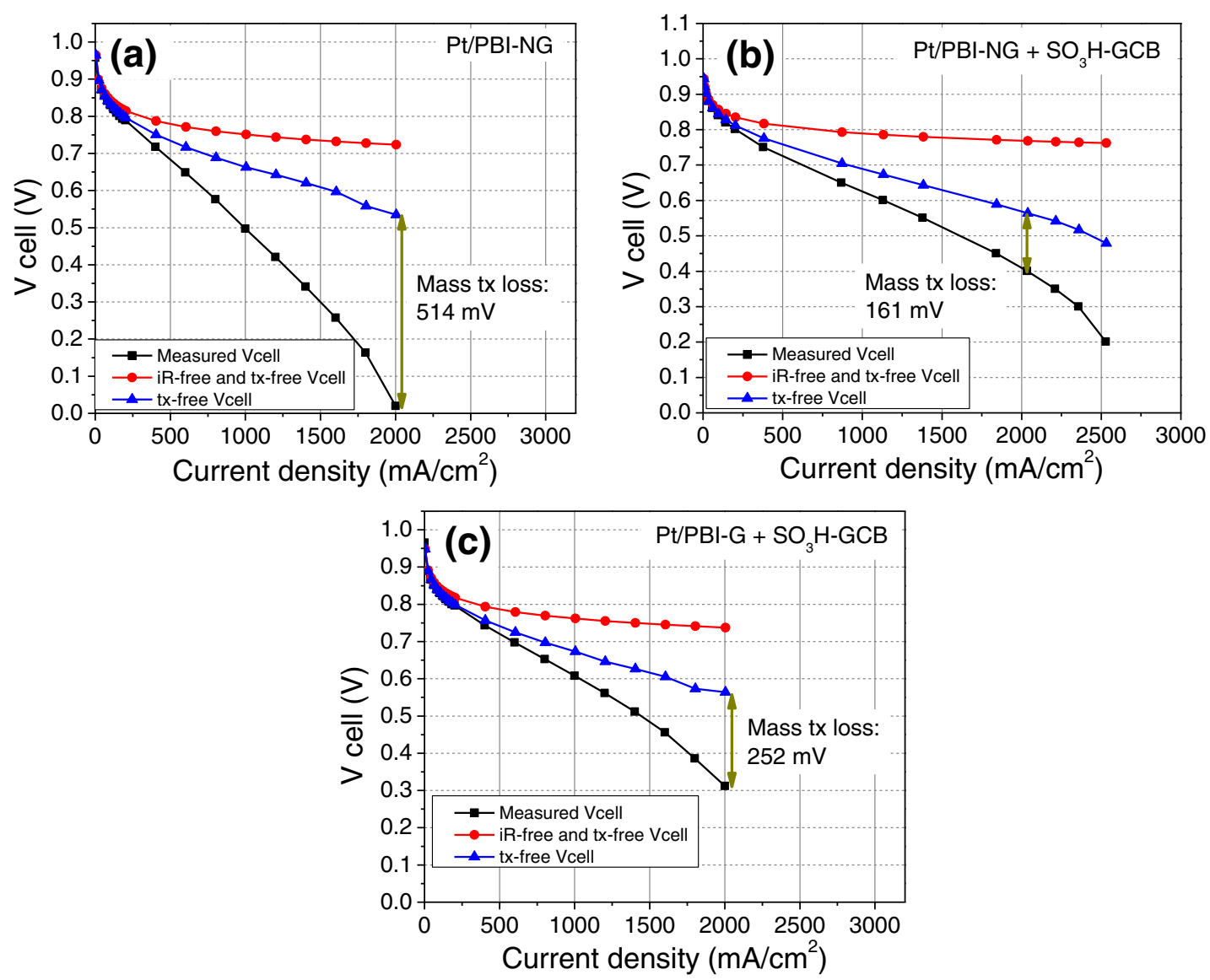

Figure 6. The beginning of life $\mathrm{H}_{2} / \mathrm{O}_{2}$ PEMFC polarization curves of the current density versus the measured cell voltage, the iR-free and mass-transport-free cell voltage, and the mass-transport-free cell voltage for (a) Pt/PBI-NG, (b) Pt/PBI-NG + $\mathrm{SO}_{3} \mathrm{H}-\mathrm{GCB}$, and (c) Pt/PBI-G $+\mathrm{SO}_{3} \mathrm{H}-\mathrm{GCB}$ cathode catalyst. 

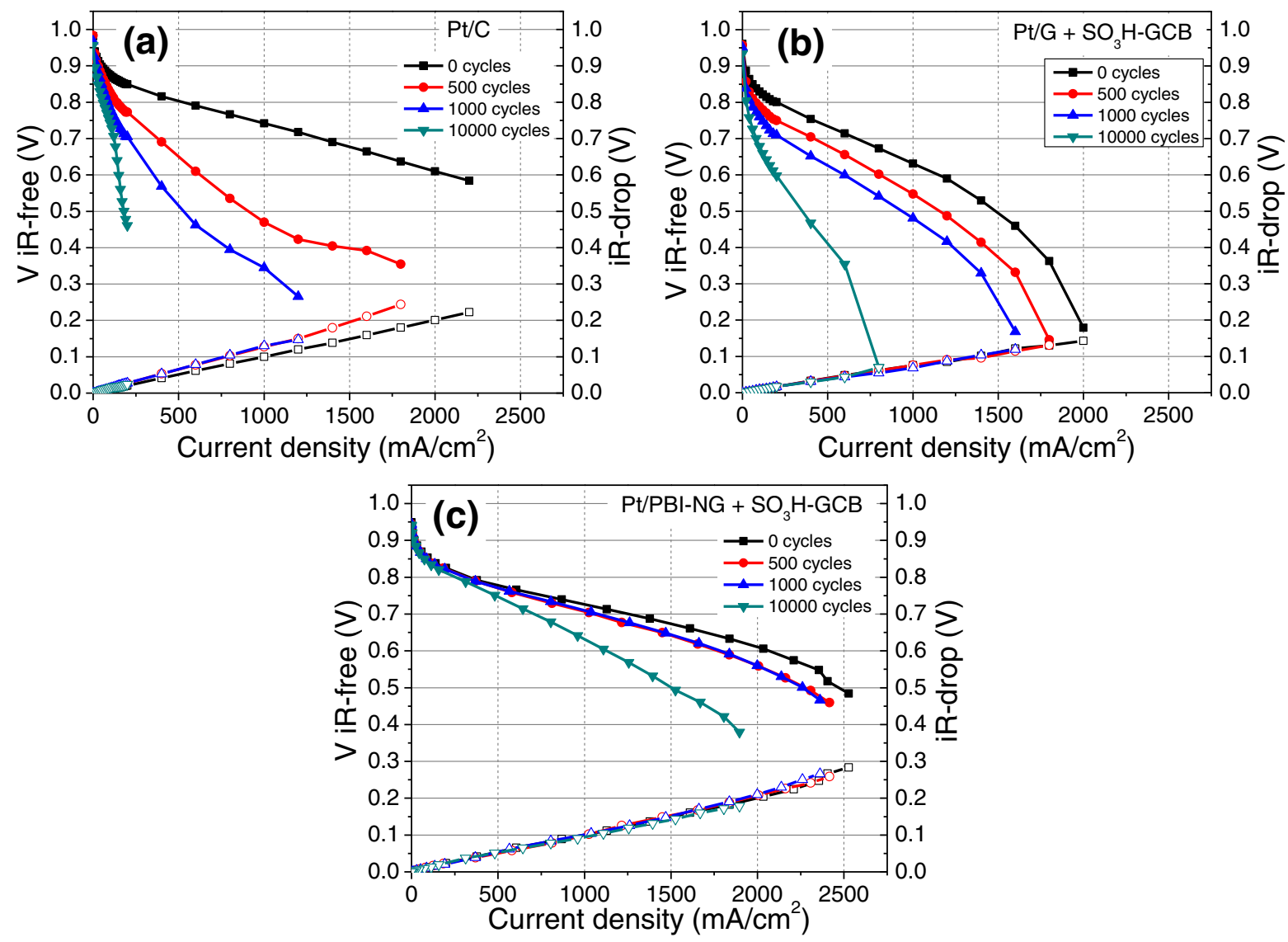

Figure 7. $\mathrm{H}_{2} / \mathrm{O}_{2}$ PEMFC polarization curves of (a) Pt/C, (b) $\mathrm{Pt} / \mathrm{G}+\mathrm{SO}_{3} \mathrm{H}-\mathrm{GCB}$ and (c) $\mathrm{Pt} / \mathrm{PBI}-\mathrm{NG}+\mathrm{SO}_{3} \mathrm{H}-\mathrm{GCB}$ before and after 10,000 cycles between $1.0 \mathrm{~V}$ to $1.5 \mathrm{~V}$. The fuel cell test conditions are: $\mathrm{H}_{2}(250 \mathrm{sccm}) / \mathrm{O}_{2}(300 \mathrm{sccm}), 80^{\circ} \mathrm{C}, 100 \% \mathrm{RH}, 280 \mathrm{kPa}_{\mathrm{abs}}$ back pressure.

that of Pt/PBI-NG (648 $\mathrm{mV})$ and Pt/PBI-G $+\mathrm{SO}_{3} \mathrm{H}-\mathrm{GCB}(725 \mathrm{mV})$, respectively.

The cell voltage of the $\mathrm{H}_{2} / \mathrm{O}_{2}$ PEMFC can be described as $\mathrm{E}_{\text {cell }}=$ $\mathrm{E}_{\mathrm{rev}}-\Delta \mathrm{E}_{\mathrm{ohmic}}-\eta_{\mathrm{ORR}}-\eta_{\mathrm{tx}}$, where $\Delta \mathrm{E}_{\mathrm{ohmic}}$ is responsible for the ohmic loss due to the resistance of proton conduction through the Nafion membrane as well as the electronic contact resistance between the fuel cell components (e.g. catalyst layer, diffusion layer, graphite flow field, and current collector); $\eta_{\mathrm{ORR}}$ contributes to the over-potential of the sluggish oxygen reduction reaction on the cathode side; $\eta_{\mathrm{tx}}$ contributes to the mass transport loss due to the poor $\mathrm{O}_{2}$ diffusion through the catalyst layers, particularly when the PEMFC operates at a high current density. The polarization curves were measured as a result of all these voltage losses. It is essentially meaningful to quantify the mass transport loss $\left(\eta_{\mathrm{tx}}\right)$ to allow the direct analysis of the benefits of the graphene's size and of using the $\mathrm{SO}_{3} \mathrm{H}-\mathrm{GCB}$ spacer on $\mathrm{O}_{2}$-transport. For this purpose, the polarization curve that is free of both ohmic loss and mass transport loss was constructed by extrapolating the IR-corrected V-I curves at a low current density $\left(<0.1 \mathrm{~A} / \mathrm{cm}^{2}\right)$ following the Tafel equation. The MEAs operating at $<0.1 \mathrm{~A} / \mathrm{cm}^{2}$ should be controlled solely by the $\mathrm{O}_{2}$ reduction reaction kinetics (e.g. $\Delta \mathrm{E}_{\mathrm{ohmic}}=\eta_{\mathrm{tx}}=0$ ). The obtained polarization curve that is purely kinetically controlled $\left(\mathrm{E}_{\mathrm{iR}-\text { free, } \mathrm{tx} \text {-free }}=\mathrm{E}_{\mathrm{rev}}-\eta_{\mathrm{ORR}}\right)$ was then added to the IR-drop recorded using a high frequency resistance (HFR) method (AC perturbation of $8 \mathrm{kHz}$ ), resulting in the masstransport-free polarization plot $\left(\mathrm{E}_{\mathrm{tx}-\text { free }}=\mathrm{E}_{\mathrm{rev}}-\eta_{\mathrm{ORR}}-\Delta \mathrm{E}_{\mathrm{ohmic}}\right)$. By comparing $\mathrm{E}_{\mathrm{tx}-\text { free }}$ with $\mathrm{E}_{\text {cell }}$, the voltage loss due to the mass transport resistance can be derived. ${ }^{55}$ As shown in Fig. 6, the PBI-NG of a smaller dimension that effectively shortens the length of the pore and the channels leads to a significant decrease in the mass transport loss for Pt/PBI-NG $+\mathrm{SO}_{3} \mathrm{H}-\mathrm{GCB}$ (161 mV, Fig. 6b) in PEMFC performance at $2.0 \mathrm{~A} / \mathrm{cm}^{2}$, compared to that of $252 \mathrm{mV}$ for Pt/PBI-G
$+\mathrm{SO}_{3} \mathrm{H}-\mathrm{GCB}$ (Fig. 6c). The comparison of cell voltage loss at a high current density between Pt/PBI-NG $+\mathrm{SO}_{3} \mathrm{H}-\mathrm{GCB}$ (161 mV, Fig. 6b) and Pt/PBI-NG (514 mV, Fig. 6a) shows significant improvement in mitigating the mass transport challenges that cause trouble for the vast applications of graphene supports in fuel cells.

The support durability of the $\mathrm{Pt} / \mathrm{PBI}-\mathrm{NG}+\mathrm{SO}_{3} \mathrm{H}-\mathrm{GCB}$ composite catalyst was evaluated under the severe corrosion conditions of accelerated stress tests (ASTs). ASTs were performed by potential cycling from $1.0 \mathrm{~V}$ to $1.5 \mathrm{~V}$ for 10,000 cycles under $\mathrm{H}_{2} / \mathrm{N}_{2}$ at $80^{\circ} \mathrm{C}, 100 \% \mathrm{RH}$ and a backpressure of $100 \mathrm{kPa}$ (absolute). Fig. 7 presents the changes of the V-I curves for Pt/C (Fig. 7a), Pt/G + $\mathrm{SO}_{3} \mathrm{H}-\mathrm{GCB}$ (Fig. 7b) and $\mathrm{Pt} / \mathrm{PBI}-\mathrm{NG}+\mathrm{SO}_{3} \mathrm{H}-\mathrm{GCB}$ (Fig. 7c) after 0, 500, 1000, and 10,000 cycles. The degradation of the PEMFC performance in terms of mass activity and cell voltage at $0.8 \mathrm{~A} / \mathrm{cm}^{2}$ and $1.5 \mathrm{~A} / \mathrm{cm}^{2}$ are compared among $\mathrm{Pt} / \mathrm{C}, \mathrm{Pt} / \mathrm{G}+\mathrm{SO}_{3} \mathrm{H}-\mathrm{GCB}$ and $\mathrm{Pt} / \mathrm{PBI}-\mathrm{NG}+\mathrm{SO}_{3} \mathrm{H}-\mathrm{GCB}$ in Fig. 8 and summarized in Table III. Pt/C demonstrates a higher initial mass activity of $452.0 \mathrm{~mA} / \mathrm{mg}-\mathrm{Pt}$ than that of both $\mathrm{Pt} / \mathrm{G}+\mathrm{SO}_{3} \mathrm{H}-\mathrm{GCB}$

Table III. Comparison of mass activity, ECSA, and cell potential losses of Pt/PBI-NG + $\mathrm{SO}_{3} \mathrm{H}-\mathrm{GCB}, \mathrm{Pt} / \mathrm{G}+\mathrm{SO}_{3} \mathrm{H}-\mathrm{GCB}$ and $\mathrm{Pt} / \mathrm{C}$ cathode catalysts before and after ASTs for 10,000 cycles.

\begin{tabular}{ccccc} 
Sample & $\begin{array}{c}\text { Mass activity } \\
\text { loss at } 0.9 \\
\mathrm{~V}_{\mathrm{iR} \text {-free }}(\%)\end{array}$ & $\begin{array}{c}\text { ECSA } \\
\text { loss } \\
(\%)\end{array}$ & $\begin{array}{c}\text { Potential loss } \\
\text { at } 0.8 \mathrm{~A} / \mathrm{cm}^{2} \\
\left(\mathrm{mV}_{\mathrm{iR} \text {-free }}\right)\end{array}$ & $\begin{array}{c}\text { Potential loss } \\
\text { at } 1.5 \mathrm{~A} / \mathrm{cm}^{2} \\
\left(\mathrm{mV}_{\mathrm{iR}-\text { free }}\right)\end{array}$ \\
\hline $\begin{array}{c}50 \mathrm{wt} \% \mathrm{Pt} / \mathrm{PBI}-\mathrm{NG} \\
+\mathrm{SO}_{3} \mathrm{H}-\mathrm{GCB}\end{array}$ & 25 & 64 & 66 & 173 \\
$50 \mathrm{wt} \% \mathrm{Pt} / \mathrm{G}$ & 59 & 71 & 602 & No activity \\
$+\mathrm{SO}_{3} \mathrm{H}-\mathrm{GCB}$ & & & & \\
$20 \mathrm{wt} \% \mathrm{Pt} / \mathrm{C}$ & 76 & 80 & No activity & No activity
\end{tabular}



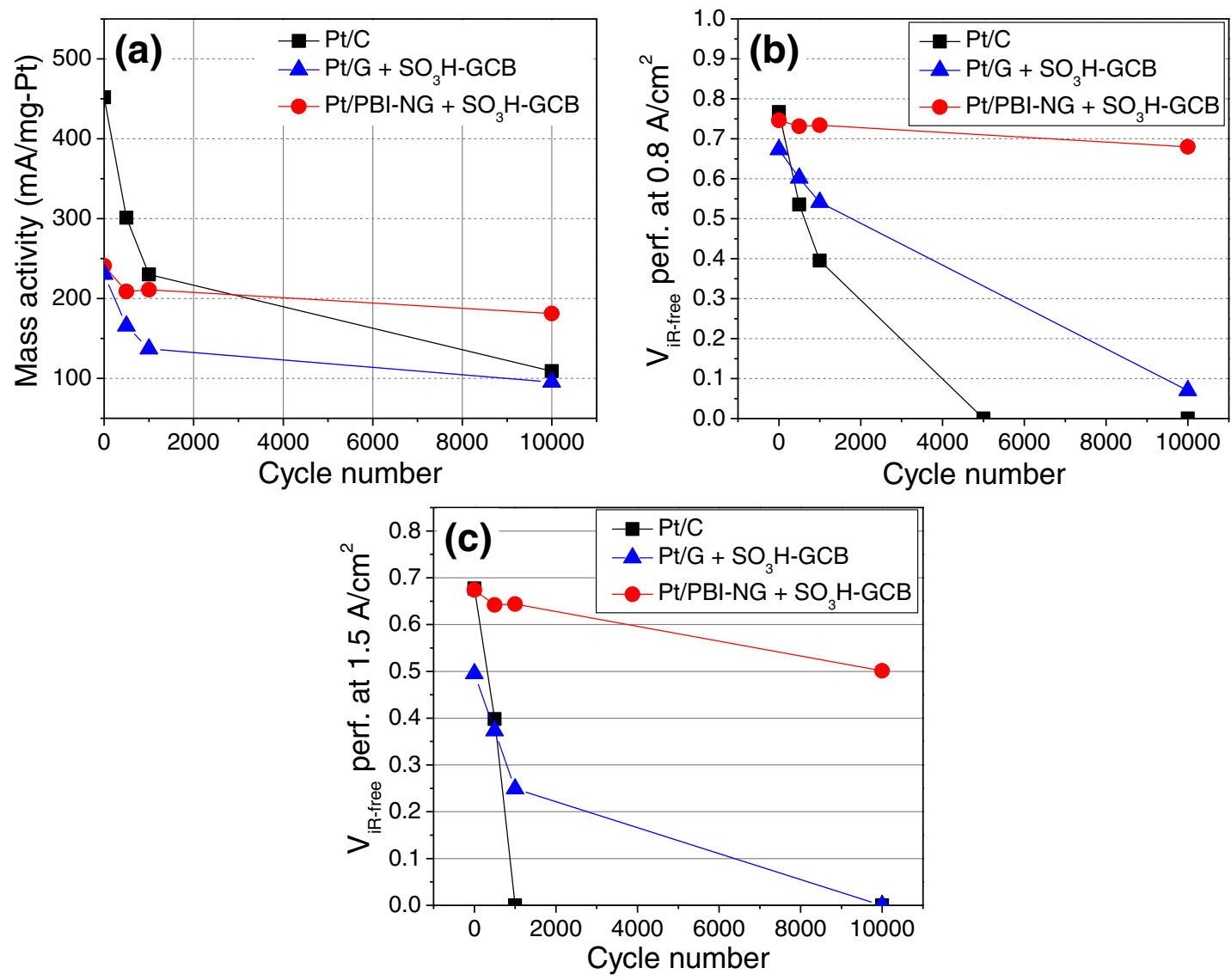

Figure 8. $\mathrm{H}_{2} / \mathrm{O}_{2}$ PEMFC performance degradations with potential cycling for $\mathrm{Pt} / \mathrm{C}, \mathrm{Pt} / \mathrm{G}+\mathrm{SO}_{3} \mathrm{H}-\mathrm{GCB}$ and $\mathrm{Pt} / \mathrm{PBI}-\mathrm{NG}+\mathrm{SO} \mathrm{H}_{3} \mathrm{GCB}$ cathode catalysts: (a) Mass activity at $0.9 \mathrm{~V}_{\mathrm{iR} \text {-free }}$; (b) $\mathrm{H}_{2} / \mathrm{O}_{2}$ performance at $0.8 \mathrm{~A} / \mathrm{cm}^{2}$; (c) $\mathrm{H}_{2} / \mathrm{O}_{2}$ performance at $1.5 \mathrm{~A} / \mathrm{cm}^{2}$.

(230.4 mA/mg-Pt) and Pt/PBI-NG + $\mathrm{SO}_{3} \mathrm{H}-\mathrm{GCB}(240.9 \mathrm{~mA} / \mathrm{mg}-\mathrm{Pt})$, which is because of the well optimized structure that promotes a higher utilization of $\mathrm{Pt}$ nanoparticles. However the Pt/C decays dramatically by $76 \%$, while the MEA of $\mathrm{Pt} / \mathrm{PBI}-\mathrm{NG}+\mathrm{SO}_{3} \mathrm{H}-\mathrm{GCB}$ retains a higher mass activity of $181.2 \mathrm{~mA} / \mathrm{mg}-\mathrm{Pt}$ higher than the $109.0 \mathrm{~mA} / \mathrm{mg}-\mathrm{Pt}$ of the Pt/C (Fig. 8a and Table III). It is also noted that the Pt/G $+\mathrm{SO}_{3} \mathrm{H}-\mathrm{GCB}$ catalyst without the surface functionalization showed mass activity loss of $59 \%$ after support stability tests. The changes in ECSA follow the same trend, where an $80 \%$ loss is seen on $\mathrm{Pt} / \mathrm{C}$, in contrast to the $64 \%$ loss on the Pt/PBI-NG $+\mathrm{SO}_{3} \mathrm{H}-\mathrm{GCB}$ and $71 \%$ loss on the Pt/G $+\mathrm{SO}_{3} \mathrm{H}-\mathrm{GCB}$ (Table III). Furthermore, the Pt/PBI$\mathrm{NG}+\mathrm{SO}_{3} \mathrm{H}-\mathrm{GCB}$ shows a slight loss of $66 \mathrm{mV}$ at $0.8 \mathrm{~A} / \mathrm{cm}^{2}$ and a $173 \mathrm{mV}$ decrease at $1.5 \mathrm{~A} / \mathrm{cm}^{2}$, whereas there is no activity observed with the $\mathrm{Pt} / \mathrm{C}$ and $\mathrm{Pt} / \mathrm{G}+\mathrm{SO} 3 \mathrm{H}-\mathrm{GCB}$ after 10,000 cycles (Figures $8 \mathrm{~b}$, $8 \mathrm{c}$, and Table III). The durability experiments indicates that PBI-NG support offers better corrosion resistance during the extensive potential cycling (up to 10000 cycles), which is likely attributed to the PBI functionalization that help to immobilize the Pt nanoparticles and, more importantly, rebuild the conjugated electron structure between PBI and nano-graphene.
X-ray photoelectron spectroscopy (XPS) was used to evaluate the content of different carbon components in NG and PBI-NG (Fig. 9 and Table IV). The deconvolution of the high resolution C 1s XPS spectra reveals that the surface functionalization of nanographene increase the relative percentage of the $\mathrm{sp}^{2}$ bonded carbon $(\mathrm{C}=\mathrm{C}, 284.5 \mathrm{eV})$ from 59.6 at.\% for NG to 69.1 at.\% for PBI-NG. The higher content of sp2 bonded carbon is possibly contributed by the covalently grafted PBI polymer that contains conjugated $\mathrm{C}-\mathrm{C}$ and $\mathrm{C}-\mathrm{N}$ bonds. On the other hand, it should be noted that PBI functionalization was performed following the aryl diazonium treatment of nanographene support using 4-aminobenzoic acid. It has been reported that the p-phenyl $\mathrm{COOH}$ radicals favors attacking graphene edges as the presence of the dangling carbon bonds and other disordered carbon structure makes them more reactive than interior of graphene sheets. ${ }^{56}$ Therefore, it is believed that the functionalization with PBI polymer on the graphene supports enables the rebuilding of the conjugated carbons that not only delocalize the electron, but also help to seal the dangling $\mathrm{C}$ bonds (i.e. defect and edge sites in a graphene sheet) results from the synthesis of graphene. Together, all of these durability tests clearly indicate the better corrosion-resistive Pt/PBI-NG $+\mathrm{SO}_{3} \mathrm{H}-\mathrm{GCB}$ composite

Table IV. Relative ratio (\%) of different carbon components in NG and PBI-NG.

Fitting of the high resolution C 1s XPS spectra [eV] (in atomic percentage /\%)

\begin{tabular}{ccccccc} 
& $\mathrm{C}=\mathrm{C}\left(\mathrm{sp}^{2}\right)$ & $\mathrm{C}-\mathrm{C} / \mathrm{C}-\mathrm{N}$ & $\mathrm{C}-\mathrm{O}$ & $\mathrm{C}=\mathrm{O} / \mathrm{C}-\mathrm{N}^{+}$ & $\mathrm{O}-\mathrm{C}=\mathrm{O}$ & $\pi-\pi^{*}$ \\
\hline Binding energy & $284.5 \mathrm{eV}$ & $285.4 \mathrm{eV}$ & $286.4 \mathrm{eV}$ & $287.5 \mathrm{eV}$ & $288.9 \mathrm{eV}$ & $289.5 \mathrm{eV}$ \\
NG & 59.6 & 16.5 & 11.9 & 3.8 & 6.9 & 1.3 \\
PBI-NG & 69.1 & 15.3 & 9.1 & 3.9 & 2.6
\end{tabular}




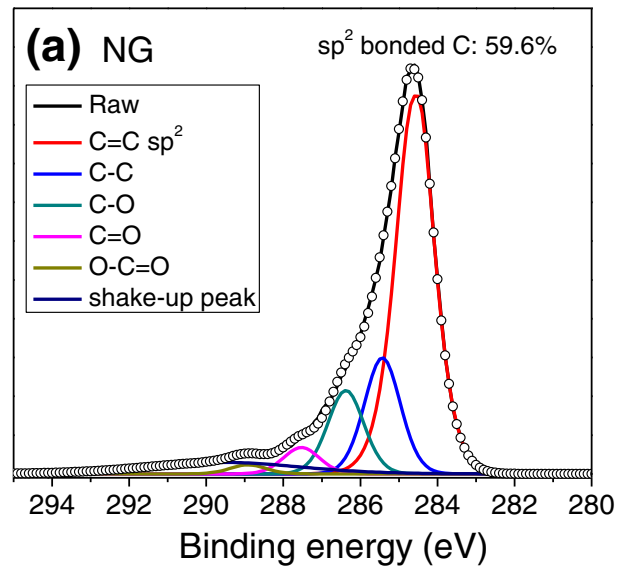

Figure 9. High resolution C 1s XPS spectra for (a) NG and (b) PBI-NG.

catalysts, largely credited to the strong binding of the Pt nanoparticles on the PBI functionalized support surface and the stable conjugated structure of the PBI-NG. ${ }^{47}$

\section{Conclusions}

This work reports a stable polybenzimidazole (PBI)-functional nanographene hybrid-supported Pt catalyst for PEMFCs. Graphitic carbon black particles, with a surface charge opposite to that of PBInanographene, were introduced and anchor on the graphene surface to make the $2 \mathrm{D}$ graphene sheets into $3 \mathrm{D}$ composite materials. In comparison with $\mathrm{Pt} / \mathrm{PBI}-\mathrm{G}$ with $\mathrm{SO}_{3} \mathrm{H}-\mathrm{GCB}$ particles and $\mathrm{Pt} / \mathrm{PBI}-\mathrm{NG}$ without the incorporation of the spacers, mercury porosimetry showed a significant increase of both primary and secondary pore volumes as a results of using nanographene due to the smaller dimensions and employing spacers. Therefore, the composite catalyst of Pt/PBI-NG $+\mathrm{SO}_{3} \mathrm{H}-\mathrm{GCB}$ promotes better Nafion ionomer coverage and facilitates facile $\mathrm{O}_{2}$ mass transport $/ \mathrm{H}_{2} \mathrm{O}$ dissipation, leading to an extra gain of activity in the $\mathrm{H}_{2} / \mathrm{O}_{2}$ PEMFC performance. Furthermore, $\mathrm{PBI}$ functionalization enhanced the dispersion of the Pt nanoparticles on the graphene/nanographene surface, and helped to terminate the dangling carbon bonds on graphene sheets so that increased the conjugated carbon matrix for stabilizing the graphene supports. The MEA of Pt/PBI-NG + $\mathrm{SO}_{3} \mathrm{H}-\mathrm{GCB}$ demonstrated superior durability compared to traditional carbon support materials (Vulcan XC72). When subjected to harsh AST conditions for 10,000 cycles, the Pt/PBI-NG + $\mathrm{SO}_{3} \mathrm{H}-\mathrm{GCB}$ exhibited mass activity and ECSA losses of $25 \%$ and $64 \%$, respectively, which was significant less than $\mathrm{Pt} / \mathrm{C}$ (76\% and $80 \%$, respectively). Additionally, the Pt/PBI-NG $+\mathrm{SO}_{3} \mathrm{H}-\mathrm{GCB}$ showed only $66 \mathrm{mV}$ loss at $0.8 \mathrm{~A} / \mathrm{cm}^{2}$ and $173 \mathrm{mV}$ loss at $1.5 \mathrm{~A} / \mathrm{cm}^{2}$ after 10,000 potential cycles between $1.0 \mathrm{~V}$ and $1.5 \mathrm{~V}$ compared to the initial performance. The reported results are close to the DOE 2020 targets for catalyst support stability. In sharp contrast, $\mathrm{Pt} / \mathrm{C}$ showed no activity at these same current densities after the ASTs. The unique advantages of the composite catalytic $\mathrm{Pt} / \mathrm{PBI}-\mathrm{NG}+\mathrm{SO}_{3} \mathrm{H}-\mathrm{GCB}$ show the potential for this to be used as catalytic material for the next generation of high surface area catalysts/supports for PEMFCs.

\section{Acknowledgments}

We acknowledge the Integrated Nanosystems Development Institute (INDI) for the use of their JEOL 7800F Field Emission Scanning Electron Microscope that was awarded under NSF grant MRI-1229514. Measurements at Los Alamos were supported by the U. S. DOE, Fuel Cell Technologies Office, Technology Development Manager: Nancy Garland.

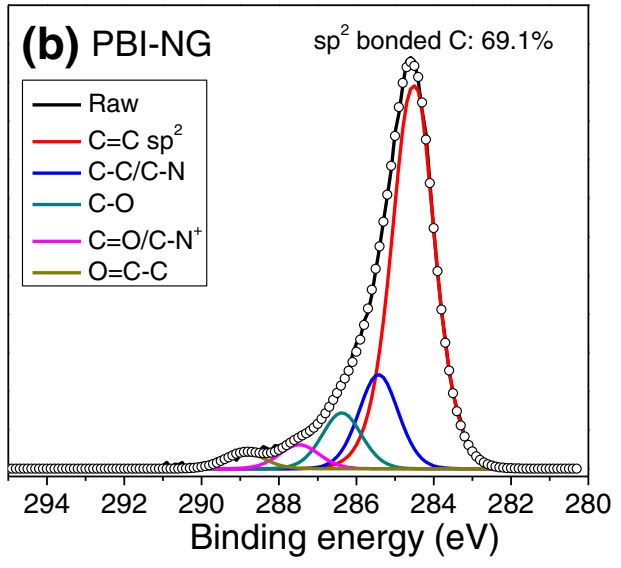

\section{References}

1. R. Borup, J. Meyers, B. Pivovar, Y. S. Kim, R. Mukundan, N. Garland, D. Myers, M. Wilson, F. Garzon, D. Wood, P. Zelenay, K. More, K. Stroh, T. Zawodzinski, J. Boncella, J. E. McGrath, M. Inaba, K. Miyatake, M. Hori, K. Ota, Z. Ogumi, S. Miyata, A. Nishikata, Z. Siroma, Y. Uchimoto, K. Yasuda, K.-i. Kimijima, and N. Iwashita, Chem. Rev., 107(10), 3904 (2007).

2. E. Antolini, Appl. Catal., B, 88(1-2), 1 (2009).

3. A. L. Dicks, J. Power Sources, 156(2), 128 (2006).

4. P. T. Yu, W. Gu, J. Zhang, R. Makharia, F. T. Wagner, and H. A. Gasteiger, in Polymer Electrolyte Fuel Cell Durability, F. N. Büchi, M. Inaba, and T. J. Schmidt, eds., p. 29, Springer New York, New York, NY, (2009).

5. F. T. Wagner, S. G. Yan, and P. T. Yu, in Handbook of Fuel Cells, John Wiley \& Sons, Ltd, (2010).

6. P. T. Yu, Z. Liu, and R. Makharia, J. Electrochem. Soc., 160(6), F645 (2013).

7. M. Oszcipok, M. Zedda, D. Riemann, and D. Geckeler, J. Power Sources, 154(2), 404 (2006).

8. H. Tang, Z. Qi, M. Ramani, and J. F. Elter, J. Power Sources, 158(2), 1306 (2006).

9. C. A. Reiser, L. Bregoli, T. W. Patterson, J. S. Yi, J. D. Yang, M. L. Perry, and T. D. Jarvi, Electrochem. Solid State Lett., 8(6), A273 (2005).

10. R. Makharia, S. Kocha, P. Yu, M. A. Sweikart, W. Gu, F. Wagner, and H. A. Gasteiger, ECS Trans., 1(8), 3 (2006).

11. K. H. Lim, H.-S. Oh, S.-E. Jang, Y.-J. Ko, H.-J. Kim, and H. Kim, J. Power Sources, 193(2), 575 (2009).

12. R. L. Borup, J. R. Davey, F. H. Garzon, D. L. Wood, and M. A. Inbody, J. Power Sources, 163(1), 76 (2006).

13. D. A. Stevens, M. T. Hicks, G. M. Haugen, and J. R. Dahn, J. Electrochem. Soc., 152(12), A2309 (2005).

14. A. Riese, D. Banham, S. Ye, and X. Sun, J. Electrochem. Soc., 162(7), F783 (2015),

15. Y. Shao, G. Yin, and Y. Gao, J. Power Sources, 171(2), 558 (2007).

16. S. R. Dhanushkodi, S. Kundu, M. W. Fowler, and M. D. Pritzker, J. Power Sources, 245, 1035 (2014).

17. K. H. Kangasniemi, D. A. Condit, and T. D. Jarvi, J. Electrochem. Soc., 151(4), E125 (2004).

18. Z. Y. Liu, J. L. Zhang, P. T. Yu, J. X. Zhang, R. Makharia, K. L. More, and E. A. Stach, J. Electrochem. Soc., 157(6), B906 (2010).

19. K. J. J. Mayrhofer, S. J. Ashton, J. C. Meier, G. K. H. Wiberg, M. Hanzlik, and M. Arenz, J. Power Sources, 185(2), 734 (2008).

20. A. Barinov, O. B. Malcioğlu, S. Fabris, T. Sun, L. Gregoratti, M. Dalmiglio, and M. Kiskinova, J. Phys. Chem. C, 113(21), 9009 (2009).

21. Y. Shao, R. Kou, J. Wang, V. V. Viswanathan, J. H. Kwak, J. Liu, Y. Wang, and Y. Lin, J. Power Sources, 185(1), 280 (2008).

22. B. Avasarala, R. Moore, and P. Haldar, Electrochim. Acta, 55(16), 4765 (2010).

23. F. Xu, M.-x. Wang, Q. Liu, H.-f. Sun, S. Simonson, N. Ogbeifun, E. A. Stach, and J. Xie, J. Electrochem. Soc., 157(8), B1138 (2010).

24. M.-x. Wang, F. Xu, Q. Liu, H.-f. Sun, R.-h. Cheng, H. He, E. A. Stach, and J. Xie, Carbon, 49(1), 256 (2011).

25. M. Hara, M. Lee, C.-H. Liu, B.-H. Chen, Y. Yamashita, M. Uchida, H. Uchida, and M. Watanabe, Electrochim. Acta, 70, 171 (2012).

26. S. Vinod Selvaganesh, G. Selvarani, P. Sridhar, S. Pitchumani, and A. K. Shukla, Fuel Cells, 11(3), 372 (2011).

27. Y. Shao, G. Yin, J. Zhang, and Y. Gao, Electrochim. Acta, 51(26), 5853 (2006).

28. S. V. Selvaganesh, P. Sridhar, S. Pitchumani, and A. K. Shukla, J Solid State Electrochem, 18(5), 1291 (2013).

29. H.-S. Oh, K. H. Lim, B. Roh, I. Hwang, and H. Kim, Electrochim. Acta, 54(26), 6515 (2009).

30. K. H. Lim, H.-S. Oh, and H. Kim, Electrochem. Commun., 11(6), 1131 (2009).

31. M.-x. Wang, F. Xu, H.-f. Sun, Q. Liu, K. Artyushkova, E. A. Stach, and J. Xie, Electrochim. Acta, 56(5), 2566 (2011) 
32. P. V. Shanahan, L. Xu, C. Liang, M. Waje, S. Dai, and Y. S. Yan, J. Power Sources, 185(1), 423 (2008).

33. K. K. Tintula, A. Jalajakshi, A. K. Sahu, S. Pitchumani, P. Sridhar, and A. K. Shukla, Fuel Cells, 13(2), 158 (2013).

34. T. Kim and B. N. Popov, Int. J. Hydrogen Energy, 41(3), 1828 (2016).

35. T. Kim, T. Xie, W. Jung, F. Gadala-Maria, P. Ganesan, and B. N. Popov, J. Power Sources, 273, 761 (2015).

36. T. Xie, W. Jung, T. Kim, P. Ganesan, and B. N. Popov, J. Electrochem. Soc., 161(14), F1489 (2014).

37. A. K. Geim and K. S. Novoselov, Nat Mater, 6(3), 183 (2007).

38. H.-J. Choi, S.-M. Jung, J.-M. Seo, D. W. Chang, L. Dai, and J.-B. Baek, Nano Energy, 1(4), 534 (2012).

39. C. H. Lui, L. Liu, K. F. Mak, G. W. Flynn, and T. F. Heinz, Nature, 462(7271), 339 (2009).

40. D. He, K. Cheng, H. Li, T. Peng, F. Xu, S. Mu, and M. Pan, Langmuir, 28(8), 3979 (2012).

41. D. He, K. Cheng, T. Peng, M. Pan, and S. Mu, J. Mater. Chem. A, 1(6), 2126 (2013).

42. Y. Si and E. T. Samulski, Chem. Mater, 20(21), 6792 (2008).

43. Y. Li, Y. Li, E. Zhu, T. McLouth, C.-Y. Chiu, X. Huang, and Y. Huang, J. Am. Chem. Soc., 134(30), 12326 (2012).
44. Y. Zhu, S. Murali, W. Cai, X. Li, J. W. Suk, J. R. Potts, and R. S. Ruoff, Adv. Mater. 22(35), 3906 (2010).

45. C. Gómez-Navarro, R. T. Weitz, A. M. Bittner, M. Scolari, A. Mews, M. Burghard, and K. Kern, Nano Lett., 7(11), 3499 (2007).

46. Z.-F. Li, L. Xin, F. Yang, Y. Liu, Y. Liu, H. Zhang, L. Stanciu, and J. Xie, Nano Energy, 16, 281 (2015).

47. L. Xin, F. Yang, S. Rasouli, Y. Qiu, Z.-F. Li, A. Uzunoglu, C.-J. Sun, Y. Liu, P. Ferreira, W. Li, Y. Ren, L. A. Stanciu, and J. Xie, ACS Catal., 2642 (2016).

48. W. S. Hummers and R. E. Offeman, J. Am. Chem. Soc., 80(6), 1339 (1958).

49. T. Fujigaya, S. Hirata, and N. Nakashima, J. Mater. Chem. A, 2(11), 3888 (2014).

50. J. Xie, K. L. More, T. A. Zawodzinski, and W. H. Smith, J. Electrochem. Soc., 151(11), A1841 (2004).

51. M. Uchida, Y. Aoyama, N. Eda, and A. Ohta, J. Electrochem. Soc., 142(12), 4143 (1995).

52. G. Gebel, Polymer, 41(15), 5829 (2000).

53. G. Gebel and B. Loppinet, J. Mol. Struct., 383(1-3), 43 (1996).

54. F. Xu, H. Zhang, J. Ilavsky, L. Stanciu, D. Ho, M. J. Justice, H. I. Petrache, and J. Xie, Langmuir, 26(24), 19199 (2010).

55. H. A. Gasteiger, S. S. Kocha, B. Sompalli, and F. T. Wagner, Appl. Catal., B, 56(1-2), 9 (2005).

56. G. L. C. Paulus, Q. H. Wang, and M. S. Strano, Acc. Chem. Res., 46(1), 160 (2013). 